\title{
Disease-Free Seed Ginger Production Technology (G3, G4 And G5) in the Field
}

\author{
Jitarpa Jijuban ${ }^{1 *}$, Wii Intrakraw ${ }^{2}$, Laddawan Insung ${ }^{3}$ and Sanong Jarinthorn ${ }^{3}$ \\ ${ }^{1}$ Department of Agriculture, Phetchabun Highland Agricultural Research Center, Thailand \\ ${ }^{2}$ Department of Agriculture, Chiangrai Horticultural Research Center, Thailand
}

${ }^{3}$ Department of Agriculture, Horticulture Research Institute, Thailand

*Corresponding author: Jitarpa Jijuban, Department of Agriculture, Phetchabun Highland Agricultural Research Center, Thailand.

To Cite This Article: Jitarpa Jijuban, Wii Intrakraw, Laddawan Insung, Sanong Jarinthorn, Disease-Free Seed Ginger Production Technology (G3, G4 And G5) in the Field. 2020 - 10(5). AJBSR.MS.ID.001548. DOI: 10.34297/AJBSR.2020.10.001548.

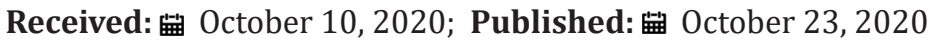

\begin{abstract}
Increasing threats of ginger from bacterial wilt: Ralstonia solanacearum, is impacted to ginger production and market of farmer in Thailand. The objective of this study was to find the integrated ginger production system that are produced high yield stability and able to replanted in the same area for farmer's well-being sustainable development. This study evaluated the integrated ginger production technology consist of cultivate management, bioproduct from Bacillus subtilis BS-DOA 24 strain for controlling bacterial wilt of ginger and disease-free rhizomes seeds from tissue culture of ginger three generations (G3, G4 and G5) at Phetchabun Highland Agricultural Research Center during October 2016- September 2019. The rhizomes seed production after planting 11 months was free from bacterial wilt disease. The sprouting ginger seed germination percentage after 2 months of G3, G4 and G5 were 92, 97 and 99\%, respectively. Total yield of DOA's technology in G3, G4 and G5 showed 3,248, 10,133 and 10,568 $\mathrm{kg} / \mathrm{rai}(20.3,63.33$, and 66.05 tons/hectare), respectively that the yield of DOA's G5 was significantly higher than farmer method $(6,725 \mathrm{~kg} / \mathrm{rai}$ or 42.03 tons/hectare).

The number of DOA's G3 branches per rhizome (17 branches) was higher than other generation. In contrast, rhizome weight of G3 in DOA technology ( $433 \mathrm{~g} /$ rhizome, respectively) was lower than another treatment however DOA's G5 (1,409 g/rhizome) was significantly heavier than farmer's technology ( $910 \mathrm{~g} /$ rhizome). The production costs of rhizomes ginger in G3 (28,817 baht/rai or 6,003.54 USD/hectare) were higher than another treatment due to high value of seeds prices in this generation. Net income of DOA's G5 showed the highest of value as 211,360 baht/rai or 44,033 USD/hectare therefore the profit (186,060 baht/rai or 38,762.5 USD/hectare) also was higher than farmer's technology. Moreover, 19 farmers were established field demonstration by using DOA's techniques and these knowledges were transferred to 137 farmers for apply in their farming. Diseases-free rhizome seeds $(9,040 \mathrm{~kg}$ ) were planted in 20.1 rais (3.216 hectare) of farmer fields at Khao Kho, Phetchabun and Kantharawichai, Maha Sarakham. In summary, the disease-free ginger production was shown to increase productivity, decrease unit cost and increase net income and net profit, and BS-DOA 24 strain bioproduct was controlled bacterial wilt in all generations after replanted in the same area.
\end{abstract}

Keywords: The disease-free seed, production, bacterial wilt, Bacillus subtilis, ginger.

\section{Introduction}

Ginger (Zingiber officinale) is an important crop of the world economy. It's a functional foods and medicinal plant in the Zingiberaceae family [1]. In 2016, the ginger export in Thailand was 44,322 tons, a value of shift million and the ginger export volume increased more than 50\% against 2017 indices. The importing countries of ginger from Thailand were Pakistan, Japan, America, New Zealand and China [2]. The development of ginger quality for exporting is an important issue to produce rhizome ginger of farmer. However, the problem of ginger production in Thailand are the bacteria wilt in ginger cause by Ralstonia solanacearum [3] that it causes yield losses over 50\% during harvests [4]. Disease symptoms show that water-soaked patches or linear streaks on the collar region of the pseudostems. Later leaves become flaccid with intense yellowish bronze color and droop. The leaves roll up and the whole plant dries in 5-7 days. Pseudostems come off easily with a gentle pull. Milky bacterial exudate oozes out on pressing 
the rhizome gently [5]. According to the problem, the farmers planted to new lands for ginger production due to avoid bacterial wilt. They used seed rhizome reserved from own production then often infected with this disease [6]. Farmer replanting ginger three generations in the same area showed that, the percent yield in the first year as $80 \%$, reduced $50 \%$ in the second year and remained $30 \%$ in the third year [7]. Moreover, the disease-free seed rhizome from tissue culture quite small size then the affect to high seed prices and high unit cost [8].

Integrated ginger production system, seed rhizome from tissue culture technique and bioproduct from Bacillus subtilis BS-DOA 24 strain that able prevented bacterial wilt (approximately 60\%) in the field [9]. In addition, the management of soil preparation with soil fumigation was mixed with urea fertilizer (0-0-46) and lime rate of $80: 800 \mathrm{~kg} /$ rai or $0.5: 5.0$ tons/hectare (1:10 ratio) to reduce the population of bacteria $R$. solanacearum before planting ginger and during ginger plant [10]. Furthermore, B. subtilis also increased the yield of ginger [11] and potato [12]. The objective of this study was to finding integrated ginger production system that are produced high yield stability and able to replanted in the same area for farmer's well-being sustainable development, environmental conservation and natural resource recovery.

\section{Materials and Methods}

\section{Plant material}

The integrated ginger production of DOA's technology, diseasefree rhizomes seeds from tissue culture of three generations (G3, G4 and G5) combined with soil preparation (urea: lime in a ratio of 1:10) and bioproduct from Bacillus subtilis BS-DOA 24 strain for controlling bacterial wilt of ginger from the Department of Agriculture (DOA), Thailand were compared with farmer's technology (Table 1). The experiment was conducted in research farm at the Phetchabun Highland Agricultural Research Center (PBHARC), khao Kho, Phetchabun (16035'35"N, 100057'50”E 742 $\mathrm{m}$ ) and extended the technology to 17 farmer's ginger production in Khao Kho, Phetchabun and Kantharawichai, Maha Sarakham during 2016-2019. A loam soil texture derived from sedimentary and metamorphic rocks, and an average annual rainfall of approximately $1,200 \mathrm{~mm}$.

\section{Testing Integrated Technology of Ginger Production}

\section{DOA Ginger Production Technology}

In the first year, the G3 disease-free seed rhizome of ginger production was produced from G2 seed rhizome in Chiang Rai Horticulture Research Center, Mueang, Chiang Rai during 20162017. After removed weeds, the management of soil preparation in one rai $(0.16$ hectare $)$ with soil fumigation was mixed with urea fertilizer (0-0-46) and lime rate of $80: 800 \mathrm{~kg} / \mathrm{rai}$ or $0.5: 5.0$ tons/ hectare (1:10 ratio). The land was plowed two times and solarized of beds in four weeks for decrease the pathogens and contamination. Beds of about $70 \mathrm{~cm}$ width, $25 \mathrm{~cm}$ height and convenient length were prepared with an interspace of $70 \mathrm{~cm}$ in between beds. Chicken manure were applied in furrow before planting with 250 $\mathrm{kg} /$ rai (1.56 tons/hectare). The seed rhizomes 7,600 plants/rais or 47,500 plants/hectare were cut into small pieces of 5-7.5 cm length each having three or four good sprouts.

These seeds were dipped with mancozeb fungicide $(50 \mathrm{~mL} / 20$ $\mathrm{L}$ of water) and cypermethrin pesticide $(50 \mathrm{~mL} / 20 \mathrm{~L}$ of water) for 30 minutes, shade dried for 30-60 minutes after that treated with B. subtilis 'BS-DOA 24' (40 mL/ $20 \mathrm{~L}$ of water) for 30 mins, shade dried. The seed rhizome bits were planted at a spacing of $30 \times 70$ $\mathrm{cm}$ and placed in shallow pits and covered with a thin layer of soil (2-5 cm). Mulching the bed with rice straw or grass straw were covered the row for protect the moisture, sun burning, and weed competition then an enclosed $1 \mathrm{~m}$ high of the net fence to protect from human and animal contamination. NPK fertilizers (15-15-15) was applied in the rate of $50 \mathrm{~kg} / \mathrm{rai}$ (0.31ton/hectare) 2 months after planting and $50 \mathrm{~kg} /$ rai (0.31 ton/hectare) of NPK (13-13-21) was applied at 4 months after planting in a furrow after removed weed, and made a horn. Spraying BS-DOA 24 bioproduct ( $40 \mathrm{~mL}$ / $20 \mathrm{~L}$ of water) every month continue to four months. However, the infection of bacterial wilt in ginger plantlet was close from the field and combined lime and urea (46-0-0) with 10:1 ratio at $500 \mathrm{~g} /$ plant.

After that, covered hold with soil and applied BS-DOA suspension ( $40 \mathrm{~mL} / 20 \mathrm{~L}$ of water) was applied at $30-50 \mathrm{~mL} /$ plant in the evening until the disease symptom appearing. The cultural and management practices i.e. irrigation and spraying for insect pest and disease control were carried out uniformly for all treatments. The ginger plants were harvested at 10-11 months after planting or when the plant's foliage or stem had died back. After collection, the seed rhizomes were determined. The G4 seed rhizomes were stored in the shade after 2 months for produced G5 seed rhizome production and testing the integrated technology of DOA's ginger production compared with farmer's technology in PBHARC during 2018-2019 (Table 1).

\section{Farmer's ginger production technology}

In the third year, the G4 seed rhizome of farmer were compared with the integrated technology of DOA's ginger production in PBHARC during 2018-2019 (Table 1). Gingers were planted in an acquiring the new area that land preparation in one rai $(0.16$ hectare) not less than one month. The land was plowed two times and solarized of beds in four weeks. Beds of about $70 \mathrm{~cm}$ width, $25 \mathrm{~cm}$ height and of convenient length were prepared with an interspace of $70 \mathrm{~cm}$ in between beds. Chicken manure were applied in furrow before planting with $250 \mathrm{~kg} / \mathrm{rai}$ (1.56 tons/hectare). The seed rhizomes were cut into small pieces of 5-7.5 cm length 
each having three or four good buds. These seeds were dipped with mancozeb fungicide $(50 \mathrm{~mL} / 20 \mathrm{~L}$ of water) and cypermethrin pesticide $(50 \mathrm{~mL} / 20 \mathrm{~L}$ of water) for 30 minutes, shade dried for 30-60 minutes.

The seed rhizome bits were planted at a spacing of $30 \times 70$ $\mathrm{cm}$ and placed in shallow pits and covered with a thin layer of soil (2-5 cm). Mulching the bed with rice straw or grass straw were covered the row for protect the moisture, sun burning, and weed competition then an enclosed $1 \mathrm{~m}$ high of the net fence to protect from human and animal contamination. NPK fertilizers (15-15-15) was applied in the rate of $50 \mathrm{~kg} / \mathrm{rai}(0.31$ ton/hectare) 2 months after planting and $50 \mathrm{~kg} /$ rai (0.31 ton/hectare) of NPK (13-13-21) was applied at 4 months after planting in a furrow after removed weed, and made a horn. The cultural and management practices i.e. irrigation and spraying for insect pest and disease control were carried out uniformly for all treatments. The ginger plants were harvested at 10-11 months after planting or when the plant's foliage or stem had died back. After collection, the seed rhizomes were determined.

\section{The Extension and Transfer of Technology}

Knowledge management in the integrated ginger seed rhizome production of DOA's technology was prepared for transfer to farmers. The seed rhizome field demonstration was established in PBHARC during 2019-2020. In addition, extension of transfer DOA's technology in ginger production for farmers via training courses and filed demonstrations at Khao Kho Agricultural Productivity Efficiency Increasing Learning Center (KKAPEILC), Phetchabun and Highland Herb Community Enterprise, Khao Kho, Petchabun.

Table 1: Ginger production technology of DOA and Thai farmer.
Finally, research presentation, publication and research service were conducted.

\section{Statistical analysis}

The data included the percentage of sprout germination, number of branches per rhizome, weight per rhizome, production per rai and cost were recoded. The experiment was laid out using a randomized completely block design (RCBD) and analyzed by using the independent t-test $(\mathrm{p} \leq 0.05)$ with two treatments and four replications. Statistical analyses were carried out using the IRRISTAT program.

\section{Results and Discussion}

\section{Testing Integrated Technology of Ginger Production}

\section{The Yield Components and Total Yield of Ginger}

Sprout germination rate of ginger rhizome seed in raised beds after planting 2 months increased in each generation (Table 2). DOA's rhizome seed in G3 generation showed 92\% sprout germination, 97\% in G4 and 99\% in G5. In addition, G5 rhizome seed of DOA's technology was lower sprout germination than seed of farmer's technology (98\%). Sprouts start to germinate because both respiration and moisture loss increase rapidly [13]. Ginger is a quantitative short-day plant and that long days tend to enhance vegetative growth while rhizome swelling is promoted by short days [14]. The optimum soil temperature for germination is between $25-26^{\circ} \mathrm{C}$, and for growth it needs $27.5^{\circ} \mathrm{C}$. A temperature in excess of $32^{\circ} \mathrm{C}$ can cause sunburn; on the other hand, low temperatures induce dormancy. Rhizome swelling promoted as the daylength was decreased from 16 to 10 hours [15].

\begin{tabular}{|c|c|c|}
\hline & DOA's Ginger Production Technology & Farmer's Ginger Production Technology \\
\hline 1 & Using the disease-free rhizomes seeds from tissue culture of G3, G4 and G5. & $\begin{array}{c}\text { Using the ginger rhizomes seed that selected from the year } \\
\text { before planting. }\end{array}$ \\
\hline 2 & $\begin{array}{c}\text { Soil preparation: replanting in the same area with disinfects of pathogens (urea } \\
\text { fertilizer and lime rate of 1:10 ratio). }\end{array}$ & Planting in the new area due to avoid pathogens. \\
\hline 3 & $\begin{array}{c}\text { Apply bioproduct from BS-DOA 24 strain (40 mL/ 20 L of water) to protect of } \\
\text { pathogens. }\end{array}$ & Non-apply bioproduct from BS-DOA 24 strain. \\
\hline
\end{tabular}

Table 2: The total yield and yield components of DOA's technology (G3, G4 and G5 rhizome seed) were compared with farmer's technology in ginger production during 2016-2019.

\begin{tabular}{|c|c|c|c|c|c|}
\hline Yield and Yield Components & \multicolumn{2}{|c|}{ DOA's Technology } & Farmer's Technology & P-value \\
\hline & G3 & G4 & G5 & G5 & \\
\hline Sprout germination (\%) & 92 & 97 & 99 & 98 & - \\
\hline Sprout number (sprouts/rhizome) & 17 & 12 & 7 & 9 & $0.055^{\text {ns }}$ \\
\hline Rhizome weight (g/rhizome) & 433 & 1,351 & 1,409 & 910 & $0.002^{*}$ \\
\hline Yield (tons/hectare) & 20.3 & 63.33 & 66.05 & 42.03 & - \\
\hline
\end{tabular}

Remarks: - Means followed by the same letter within a column are not significantly different at $5 \%$ level of significance by the independent $t$-test method.

- DOA's technology = cultivate management, bioproduct from B. subtilis BS-DOA 24 strain and disease-free seeds rhizomes of ginger (G3, G4 and G5 generations).

- Farmer's technology = cultivate management and farmer's rhizome seed. 
The number of branches per rhizome decreased in each generation due to initial generation (G3) of seed size represented small size and became large in G5 (Table 2). Then, branches number in G5 of D0A's technology (7 branches/rhizome) was less than G5 of farmer's technology ( 9 branches/rhizome) but not significantly different from the farmer treatments. However, the rhizome size of DOA's technology was larger than rhizome of farmer's technology. These results are similar with the study of [16] revealed that ginger plantlets from meristem micropropagation produced more tillering and rhizome branching when compared with conventional method (old rhizomes). The weight of rhizome in G3 (433 g/rhizome), G4 $(1,351 \mathrm{~g} /$ rhizome $)$ and G5 (1,409 g/rhizome) increased in each generation (Table 2). Rhizome weight in G5 that treated with DOA's technology was significantly heavier than that from the farmer's technology ( $910 \mathrm{~g} /$ rhizome). Our results demonstrate that, besides to those of three biocontrol agents (BCAs) namely B.subtilis, Trichoderma album and Trichoderma hamatum enhanced the average tuber weight of potato [17].

Total yield per rai of rhizome in G5 of DOA's technology (10,568 $\mathrm{kg} / \mathrm{rai}$ or 66.05 tons/hectare) was higher than G4 $(10,133 \mathrm{~kg} / \mathrm{rai}$ or 63.33 tons/hectare) and G3 (3,248 kg/rai or 20.30 tons/hectare), respectively (Table 2). There was higher than ginger that treated with farmer's technology $(6,725 \mathrm{~kg} / \mathrm{rai}$ or 42.031 tons/hectare). These results are similar to those of [11] reported that BS-DOA
24 improved the ginger production at $4,288.03 \mathrm{~kg} / \mathrm{rai}$ which more than control [12] indicated that the application of a microbial product of $B$. subtilis strain increased tuber yield by fostering the recruitment of beneficial bacteria in the potato rhizosphere [12]. In addition, $B$. subtilis had properties to be plant growth promoting microorganism and mechanism to suppress disease caused by pathogen which increase crop productivity [18].

\section{The Production Costs of Ginger}

The important production cost of ginger production was the rhizome seed in each generation (Table 3). The rhizome seed cost in G5 of farmer's technology (10,108 baht/rai or 2,105.83 USD/ hectare) was higher than DOA's technology in G3 (6,156 baht/rai or 1,282.50 USD/hectare), G5 (2,128 baht/rai or 443.33 USD/hectare) and G4 (1,748 baht/rai or 364.17 USD/hectare), respectively. The bioproduct from BS-DOA 24 strain for controlling bacterial wilt of ginger that treated in the DOA's technology was increased production cost in each generation. However, the integrated ginger production of DOA's technology were increased yield of ginger then also increased income and profit of ginger production. DOA's technology income in G5 (211,360 baht/rai or 44,033.33 USD/ hectare) and G4 (202,660 baht/rai or 42,220.83 USD/hectare) was higher than G5 of farmer's technology $(134,500$ baht/rai or 28,020.83 USD/hectare).

Table 3: The production cost of DOA's technology (G3, G4 and G5 rhizome seed) were compared with farmer's technology in ginger productions during 2016-2019.

\begin{tabular}{|c|c|c|c|c|}
\hline Item & \multicolumn{2}{|c|}{ DOA's Technology } & Farmer's Technology \\
\hline & G3 & G4 & G5 & G5 \\
\hline Ginger rhizome seed (Baht/rai) & 6156 & 1748 & 2128 & 2075 \\
\hline Ginger rhizome seed (USD/hectare) & 1282.5 & 364.17 & 443.33 & 2078.13 \\
\hline Material cost (USD/hectare) & 2804.38 & 3016.04 & 2910.83 & 2076.46 \\
\hline B. subtilis (USD/hectare) & 916.67 & 916.67 & 916.67 & - \\
\hline Labor cost (USD/hectare) & 1000 & 1000 & 1000 & 1000 \\
\hline Total costs (USD/hectare) & 6003.54 & 5296.88 & 5270.83 & 5182.29 \\
\hline Income (USD/hectare) & 13533.33 & 42220.83 & 44033.33 & 28020.83 \\
\hline Profit (USD/hectare) & 7529.79 & 36923.96 & 38762.5 & 22838.54 \\
\hline BCR & 1,25 & 6.97 & 7.35 & \\
\hline
\end{tabular}

Remark: planting area of 1 rai $=6.25$ hectares.

Similarly, ginger production in G5 of DOA's technology (186,060 baht/rai or 38,762.50 USD/hectare) was showed the highest net profit production. NdaNmadu revealed that labor, seed, fertilizer and capital inputs were significant in explaining the output [19]. The mean technical efficiency of 0.799 indicate that an average ginger farmer in the study area will enjoy an output increase of $18.55 \%$ if management techniques are improved and attains the level of the most efficient ginger farmer. Among the various inputs, cost of labour (50.57\%) and planting materials $(30.38 \%)$ contributed higher to the total variable cost of production [20]. However, bioproduct BS-DOA 24 strain increased productivity then increased the profitability of ginger production $[12,18]$.

\section{The Extension and Transfer of Technology}

Knowledge management in the integrated ginger seed rhizome production of DOA's technology was consisted knowledge of soil preparation, the seed rhizomes preparation, cultivation and farm maintenance, pest and disease management, fertilizer and 
nutrient management, harvest and postharvest, packaging and transportation. These techniques were emphasized cultivation by using the disease-free rhizomes seeds from tissue culture of G3, G4 and G5, soil preparation by using urea fertilizer (0-0-46) and lime rate of $80: 800 \mathrm{~kg} /$ rai or $0.5: 5.0$ tons/hectare (1:10 ratio) and applying bioproduct from BS-DOA 24 bacteria of $40 \mathrm{~mL} / 20 \mathrm{~L}$ of water for 30 mins to protect of pathogens.

The seed rhizome field demonstration of DOA's technology was established in PBHARC during 2019-2020. 17 farmers from Khao Kho, Phetchabun and Kantharawichai, Maha Sarakham received disease-free seed rhizome of ginger approximately 9,040 $\mathrm{kg}$ in 3.056-hectares (19.1 rais) area planting and BS-DOA 24. Furthermore, they were confident DOA's technology and applied this technique in their farm. In addition, extension of transfer DOA's technology in ginger production for farmers via filed demonstrations at Khao Kho Agricultural Productivity Efficiency Increasing Learning Center (KKAPEILC). Supporting the G5 and G6 disease-free seed rhizomes was as $800 \mathrm{~kg}$ and two $\mathrm{kg}$ of BS-DOA 24 to learning center. In 2019, the learning center produced 8,000 $\mathrm{kg}$ seed rhizomes and distribute to other farmers then increased net profit about 25,000 USD/hectare (120,000 baht/rai). Moreover, the integrated seed rhizome production of DOA's extended to Phetchabun and Highland Herb Community Enterprise, Khao Kho, Petchabun in 2019.

The seed rhizome $(1,000 \mathrm{~kg})$ planted in field demonstration and treated with $2 \mathrm{~kg}$ of BS-DOA 24 bioproduct. At least 100 farmers in organization improved their skills and knowledge via DOA's training courses. They were satisfied and applied this technology to produce in Zingiberaceae family such as cassumunar (Zingiber cassumunar Roxb.), turmeric (Curcuma longa) and Black Galingale (Kaempferia parviflora Wallich. ex Baker.). Moreover, 50 farmers improved knowledge and 9,040 kg seed rhizomes were distributed to 4.56 hectares (28.5 rais) of farmers in ginger farming. Furthermore, to represent PR performance e.g. four papers of research presentation and publication, research service and welcome visiting delegations from Khao Kho, Phetchabun more than 250 persons.

\section{Conclusion}

The integrated ginger production DOA's technology was shown to be an appropriate method for soil preparation (urea: lime in a ratio of 1:10) combine with disease-free rhizomes seeds from tissue culture of three generations (G3, G4 and G5) and bioproduct from B. subtilis BS-DOA 24 strain for controlling bacterial wilt of ginger. This technology increased yield and rhizome weight and decreased the total costs of ginger production. The farm income increased then increased quality of a livelihood in the farming households. Moreover, 19 farmers were established field demonstration by using DOA's techniques and these knowledges were transferred to
137 farmers for apply in their farming.

\section{Acknowledgement}

The authors would like to acknowledge support from the Department of Agriculture for contributed this research program. Special thanks to ginger project team who have kindly assisted, supported and make this research a success.

\section{References}

1. Shoaib M, Shehzad A, Butt MS, Saeed M, Raza H, et al. (2016) An overview: ginger, a treamendous herb. Global Innovations in Agricultural and Social Sciences 4(4): 172-187.

2. Thunyakaset T (2019) Ginger. Bureau of Agricultural Commodities Promotion and Management, Department of Agricultural Extension, Ministry of Agriculture and Cooperatives, Thailand.

3. Hayward AC (1991) Biology and epidemiology of bacterial wilt caused by Pseudomonas solanacearum. Annual Review of Phytopathology 29: 65-87.

4. Yu Q Alvarez AM, Moore PH, Zee F, Kim MS, et al. (2003) Molecular diversity of Ralstonia solanacearum isolated from ginger in Hawaii. Phytopathology 93(9): 1124-1130.

5. Raghu S (2011) Studies on management of rhizome wilt of ginger with special reference to Ralstonia solanacearum (E. F. Smith) Yabuuchi et al. Master of Science (Agriculture) in Plant Pathology, India p.78.

6. Jijuban (2020) Replanting ginger in the same area . Kasikorn 93(5): 6573.

7. Insung L (2015) Research project report of research and development on ginger production technology of quality. Thailand p. 78.

8. Intakaew W, Kositcharoenkul N, Chomchei J, Puttawong S, Sittinam T, et al. (2019) Research project report of breeding and ginger production technology. Thailand.

9. Kositcharoenkul N, Boonsuebsakul W, Wisesssang O, Tassakorn T (2004) The study of application of Bacillus spp. to control bacterial wilt in ginger and tomato 115-126.

10. Puawongphat B, Kositcharoenkul N, Tongkreng R, Insung L, Jijuban, et al. (2012) Integrated Management of Ginger bacterial wilt disease caused by Ralstonia solanacearum. p. 497-505.

11. Kositcharoenkul N, Puawongphat B, Kanhayart T, Tongkreng R (2014) Development of bioproduct of Bacillus subtilis BS-DOA 24 strain for controlling bacterial wilt of ginger. Thai Agricultural Research Journal 32(3): 234-251.

12. Wang Z, Li Y, Zhuang L, Yu Y, Liu J, et al. (2019) A Rhizosphere-derived consortium of Bacillus subtilis and Trichoderma harzianum suppresses common scab of potato and increases Yield. Computational and Structural Biotechnology Journal 17: 645-653.

13. Pringle A, Bever JD, Gardes M, Parrent JL, Rillig MC, et al. (2009) Mycorrhizal symbioses and plant invasions. Annual Review of Ecology, Evolution, and Systematics 40: 699-715.

14. Smith MK, Hamill SD (1996) Field evaluation of micropropagated and conventionally propagated ginger in subtropical Queensland. Australian Journal of Experimental Agriculture 36: 347-354.

15. Fikre T, Kifle A (2013) Ginger (Zingiber Oficinale Rosec.): production, postharvest handling, processing and marketing - A comprehensive extension package manual. FARM AFRICA, Ethiopia p. 125. 
16. Thaveechai N, Sahavacharin 0, Sagwansupyalorn C, Rama Raj P (1997) Effect of planting material on growth and seed rhizome yield of ginger (Zingiber officinale Roscoe). Thailand 31(4): 445-451.

17. Abd-El-Khair H, Self El-Nasr HI (2011) Applications of Bacillus subtilis and Trichoderma spp. for controlling the potato brown rot in field. Journal Archives of Phytopathology and Plant Protection 45(1): 1-15.

18. Hashem A, Tabassum B, Fathi Abd Alldh E (2019) Bacillus subtilis: a plant-growth promoting rhizobacterium that also impacts biotic stress. Saudi Journal of Biological Science 26(6): 1291-1297.
19. Nda Nmadu J (2013) Efficiency of ginger production in selected local government areas of Kaduna State, Nigeria. IJFAEC 1(2): 39-52.

20. Ewuziem JE, Onyenobi VO (2012) Cost and return analysis of ginger production in the Guinea Savannah of Nigeria. Journal of Tropical Agriculture and Food Science 10(2): 26-36. 